\title{
Cadaverből és multiorgan donorból származó szaruhártyák túlélése 2008 és 2017 között klinikánkon
}

\author{
Kovács Klaudia dr. ${ }^{1}$ - Szentmáry Nóra dr. ${ }^{1,2}$ - Pluzsik Milán Tamás dr. ${ }^{1}$ \\ Langenbucher Achim dr. ${ }^{3}$ - Kiss Huba dr. ${ }^{1}$ - Füst Ágnes dr. ${ }^{1}$ \\ Kriskó Dorottya dr. ${ }^{1}$. Rácz Gergely dr. ${ }^{4}$ \\ Matolcsy András dr. ${ }^{4}$ - Nagy Zoltán Zsolt dr. ${ }^{1}$
}

\author{
${ }^{1}$ Semmelweis Egyetem, Általános Orvostudományi Kar, Szemészeti Klinika, Budapest \\ ${ }^{2}$ Dr. Rolf M. Schwiete Zentrum für Limbusstammzellforschung und kongenitale Aniridie, \\ Homburg/Saar, Németország \\ ${ }^{3}$ Experimentelle Ophthalmologie, Universität des Saarlandes, Homburg/Saar, Németország \\ ${ }^{4}$ Semmelweis Egyetem, Általános Orvostudományi kar, I. Patológiai és Kísérleti Rákkutató Intézet, Budapest
}

Bevezetés: Az első szaruhártya-bank 1944-es alapítása óta jelentős változásokon ment át. A szaruhártya túlélését számos tényező befolyásolja, így a tárolási mód, melynek a szövet lejárati ideje szerint rövid, közép és hosszú távú módszereit fejlesztették ki.

Célkitüzés: Retrospektív vizsgálatunk célja a 2008. január 1. és 2017. december 31. között perforáló és lamelláris keratoplasztika során felhasznált cadaverből és multiorgan donorból származó szaruhártyák túlélésének vizsgálata volt a Semmelweis Egyetem Szemészeti Klinikáján.

Módszer: Feljegyeztük a recipiens nemét, életkorát, a műtétet indikáló klinikai diagnózist, a mưtét időpontját, a szövettani vizsgálat eredményét, valamint, hogy a beültetett szaruhártya cadaverből vagy multiorgan donorból származott. Meghatároztuk, hogy a recipiens életkora korrelált-e a rekeratoplasztikáig eltelt idóvel.

Eredmények: 1451 szaruhártya-átültetés történt 1088 beteg (44,6\% férfi) 1159 szemén (életkor 62,8 $\pm 18,5$ év), melyek között $938(64,6 \%)$ cadaver és $262(18,0 \%)$ multiorgan donor került felhasználásra, 251 esetben (17,2\%) nem állt rendelkezésre adat. A leggyakoribb primer diagnózis a szaruhártya-dekompenzáció volt (325 eset, 28\%). A primer keratoplasztikák során felhasznált szaruhártyák 740 esetben $(63,8 \%)$ cadaverból, 212 esetben (18,2\%) multiorgan donorból származtak, 207 esetben (17,8\%) nem állt rendelkezésre adat.

Első rekeratoplasztika a primer keratoplasztikák közül 217 esetben (18,7\%) történt. A leggyakoribb szövettani diagnózis az endothelsejt-degeneráció volt (130 esetben, 60,4\%). 146 esetben (67,2\%) korábban cadaver, 31 esetben (14,2\%) multiorgan donor esetén került sor ismételt mútétre, 40 esetben $(18,4 \%)$ nem állt rendelkezésre adat.

Következtetés: Klinikánkon elsősorban cadaverből származó donorok biztosítják a szaruhártya átültetésekhez szükséges szövetet. Cadaverből vagy multiorgan donorból származó szaruhártyák esetén nem kerül gyakrabban sor rekeratoplasztikára. A szaruhártya-banki tevékenység további fejlesztésével növelhető a donorok túlélése hazánkban.

Orv Hetil. 2021; 162(13): 488-496.

Kulcsszavak: multiorgan donor, cadaver, keratoplasztika, graftelégtelenség

\section{Graft survival using cadaver and multiorgan donors between 2008 and 2017 in our department}

Introduction: Corneal banking methods have been changing since the foundation of the first corneal bank in 1944 . Corneal graft survival may be affected by several factors, among others the storage method, which may be short-, middle- and long-term storage.

Objective: To investigate corneal graft survival at the Department of Ophthalmology, Semmelweis University between 1 January 2008 and 31 December 2017, using cadaver and multiorgan donors for penetrating and lamellar keratoplasty, retrospectively.

Method: Recipient sex, age, clinical diagnosis, date of surgery, histological examination results and origin of donors (cadaver or multiorgan donor) were recorded. Correlation between recipient age and time to repeat keratoplasty was also analyzed. 
Results: There were 1451 keratoplasties in 1159 eyes (age $62.8 \pm 18.5$ years) of 1088 patients (44.6\% male) using $938(64.6 \%)$ cadaver and $262(18.0 \%)$ multiorgan donors, data was not available in $251(17.2 \%)$ cases.

There was repeat keratoplasty in 217 patients (18.7\% of first keratoplasties). The most common histological diagnosis was endothelial decompensation (130 cases, 60.4\%) in these cases. In patients with a first repeat keratoplasty, in 146 cases $(67.2 \%)$ the first donor originated from cadavers, in 31 cases $(14.2 \%)$ from multiorgan donors and in 40 cases $(18.4 \%)$ data were not available.

Conclusion: Corneal donors mainly originate from cadavers at our Department. The necessity of repeat keratoplasties does not differ using cadaver or multiorgan donors. With further development of corneal banking, donor survival may be increased in Hungary.

Keywords: multiorgan donor, cadaver, keratoplasty, graft failure

Kovács K, Szentmáry N, Pluzsik MT, Langenbucher A, Kiss H, Füst Á, Kriskó D, Rácz G, Matolcsy A, Nagy ZZs. [Graft survival using cadaver and multiorgan donors between 2008 and 2017 in our department]. Orv Hetil. 2021; 162(13): 488-496.

(Beérkezett: 2020. augusztus 3.; elfogadva: 2020. szeptember 9.)

\section{Rövidítések}

EBAA $=($ Eye Bank Association of America $)$ Amerikai Szem Bank Társaság; ECD = (endothelial cell densitiy) edothelsejtdenzitás; EEBA $=$ (European Eye Bank Association) Európai Szem Bank Társaság

Becslések szerint 285 millió ember látássérült a világon, közülük 39 millióan vakok. A szaruhártya homályai és a trachoma világszerte a vakság 3-4\%-ért felelősek [1]. A szaruhártya homályaiért ritka, de súlyos szisztémás betegségek is felelhetnek, amelyek felismerése döntő jelentőségú (például cystinosis, monoklonális gammopathia, Wilson-kór) [2]. A cornealis vakságnál csupán a cataracta $(51 \%)$, valamint a glaucoma $(8 \%)$ gyakoribb vaksági okok [1]. Jól szervezett, megfelelő időben végzett szaruhártya-átültetéssel számos beteg látása jelentősen javítható.

Évente közel 185 ezer cornea-transzplantációt végeznek a világ több mint 115 országában, ebből mintegy 80 ezer mútét az Amerikai Egyesült Államokban történik. A donor corneák $87 \%$-át a harvesztáló országban használják fel, míg 27 ország cornealis allograft-szükségletét kizárólag importált szaruhártyákból fedezi (corneatranszplantációk 1,2\%-a). Az életképes graftszövethez való korlátozott hozzáférés továbbra is kihívást jelent a világ számos részén, a populáció több mint fele emiatt nem kerül szaruhártya-átültetésre [3].

Az első sikeres szaruhártya-átültetést 1905. december 7-én az osztrák szemész főorvos, Dr. Eduard Konrad Zirm (1863-1944) végezte el [4, 5]. Az 1920-as, 1930as években a lamellaris keratoplasztikát kifejlesztő orosz szemész, Vladimir Filatov elsóként használt fel cadaver szaruhártyát [6]. Ma már tudjuk, hogy ötlete mérföldkőnek számított, de technikai feltételek és megfelelő tárolás hiányában ez a módszer nem terjedt el. Az 1940-es évekig a szaruhártya-donorok az enucleált, élő betegek, az állami kórházakban elhunytak, illetve a börtönben kivégzett elítéltek voltak.
1944. december 15-én Dr. Richard Townley Paton létrehozta az első szembankot (Eye Bank for Sight Restoration, New York) [6]. Ezzel megteremtette a cadaver szaruhártyák felhasználásának lehetőségét. Számos cornea bank megalakulását követôen 1961 októberében 25 szembankkal megalakult Amerika első transzplantációs társasága, az Eye Bank Association of America (EBAA, Chicago). Az 1970-es évektól a cornea bankok száma Nyugat-Európában is jelentősen emelkedett, valamint Niels Ehlers vezetésével megalakult a European Eye Bank Association (EEBA).

Noha a szembankok megalapítása jelentősen növelte a szaruhártya-ellátottságot, a mútéteket mégis sürgősen kellett végrehajtani, hiszen a szaruhártyák tárolási ideje csupán 2-3 nap volt [7]. A tárolásnak később a szövet lejárati ideje szerint rövid, közép és hosszú távú módszereit fejlesztették ki. A rövidtávú tárolás legkorábbi formája a bulbus $+4^{\circ} \mathrm{C}$-on, párakamrában történő tárolása volt [4]. 1974-ben McCarey és Kaufman bevezette a róluk elnevezett tápoldatot, a rövidtávú tárolás későbbi változatát. A középtávú tárolás az előbb említett hypothermikus médium chondroitin-szulfáttal történő kiegészítésével (K-sol, Dexsol, Optisol) vált lehetővé. Az antibiotikumok hatékonyságának növelésével a tárolási idő elóbb 7-10 napra [7], majd további módosításokkal 14 napra nőtt. Az eredetileg Doughman nevéhez füződő szövettenyészetben történő, hosszú távú tárolást Angliában fejlesztették tovább. Ezzel a módszerrel a szaruhártyákat fiziológiás hőmérsékleten, több mint 30 napig tárolhatták, így a mútétek időpontját megtervezhették [8].

Az első sikeres szaruhártya-átülttetést Magyarországon 1909. szeptember 28-án Fejér Gyula végezte [9]. 1993 júliusában megalakult az első önálló magyar szaruhártya szövetbank, a Cornea Bank Budapest, mely által 25 év alatt preparált 15000 szaruhártyából több mint 10000 került beültetésre [4]. Nem sokkal a fővárosi szembank megalakulása után, 1994-ben nyitotta meg kapuit a 
Debreceni Cornea Bank. Budapesten a Semmelweis Cornea Bank 2004. december 31 -én kezdte meg munkáját. Mindhárom szembank az EEBA tagja [10], mely jelenleg 24 ország 84 szövetbankjának múködését fogja össze [11]. Napjainkban az Európai Szem Bank Társasághoz tartozó szaruhártya-bankok évente közel 40 ezer szaruhártyát preparálnak, melyeknek kétharmada kerül beültetésre [4].

A Semmelweis Egyetem Szemészeti Klinikáján 2008 januárjától két forrásból jutottunk transzplantálható corneákhoz: ún. szervdonációk alkalmával agyhalottból történő enucleatióval (multiorgan donor), illetve cadaverekből. Az előbbi a Semmelweis Cornea Bank, utóbbi a Budapest Cornea Bank által szolgáltatott szaruhártyákat foglalta magába. Mindkét csoportban középtávú tárolás (14 nap) történt.

Az életképes graftszövethez való korlátozott hozzáférés világszintû́ probléma, ezért különösen fontos a beültetett szaruhártya túlélését befolyásoló tényezők ismerete. A nemzetközi irodalomban számos adatot találtunk arra vonatkozóan, hogy a donor szaruhártya recipiensben való túlélését mely tényezők miként befolyásolják (például a donor életkora, preoperatív diagnózis, a graft átmérője, korai varrateltávolítás, a beültetett szaruhártya neovaszkularizációja, kilökődési reakció megjelenése, posztoperatív szemnyomás-emelkedés stb.) [12]. A cadaverből és multirogan donorból származó szaruhártyákkal kapcsolatban azonban kevés adat elérhető.

Retrospektív vizsgálatunk célja a 2008. január l. és 2017. december 31. között perforáló és lamellaris keratoplasztika céljából felhasznált cadaver és multiorgan donorból származó szaruhártyák túlélésének vizsgálata volt a Semmelweis Egyetem Szemészeti Klinikáján.

\section{Betegek és a módszer}

Vizsgálatunk során a 2008. január 1. és 2017. december 31. között perforáló és lamellaris keratoplasztikán átesett betegek klinikai és mütéti adatait, valamint az explantált szaruhártya korongok szövettani vizsgálati eredményét tekintettük át. Kizárásra kerültek azok az esetek, akiknél 2008 előtt történt az első szaruhártya-átültetés.

Feljegyeztük a recipiens nemét, életkorát, a mütétet indikáló klinikai diagnózist, a mütét időpontját, a szövettani vizsgálat eredményét, valamint, hogy a beültetett szaruhártya cadaverből vagy multiorgan donorból származott. A cadaver és multiorgan szaruhártyák tárolási módja a vizsgált időszakban megegyezett: a preparálást követően Optisol tápoldatban, hütőszekrényben elhelyezve $\left(+4^{\circ} \mathrm{C}\right) 14$ napon belül kerültek felhasználásra.

Primer keratoplasztikák esetén a Brady által kidolgozott diagnosztikai csoportok alapján összesen 10 betegcsoportot hoztunk létre: cornea-dekompenzáció; akut nekrotizáló és ulceratív keratitis; keratoconus; cornealis heg/homály; Fuchs-dystrophia; cornea-dystrophia (Fuchs kivételével), egyéb diagnózis; a hiányos dokumentáció miatt nem meghatározott (nem ismert) diag- nózis. A rekeratoplasztika csoporton belül a szövettani vizsgálat eredménye alapján a következő alcsoportokat hoztuk létre: endothelsejt-degeneráció; a transzplantátum-nekrózis vagy -neovaszkularizáció; kilökődési reakció; ulceratív keratitis; cornea-dystrophia; szaruhártyaheg vagy -homály; egyéb; a hiányos dokumentáció miatt nem meghatározott (nem ismert) diagnózis.

\section{Eredmények}

Retrospektív vizsgálatunkban a Semmelweis Egyetem Szemészeti Klinikáján 2008. január 1. és 2017. december 31. között, 1088 beteg (44,6\% férfi, 51,7\% nő) 1159 szemén történt szaruhártya-átültetést elemeztük. A betegek életkora a mútét idején 62,8 \pm 18,5 év volt, 938 cadaver és 262 multiorgan donor került felhasználásra (251 esetben nem állt rendelkezésre adat).

\section{Primer keratoplasztikák}

A primer szaruhártya-átültetések indikációja 325 esetben $(28,1 \%)$ cornea-dekompenzáció, 238 esetben (20,5\%) akut nekrotizáló és ulceratív keratitis, 122 esetben (10,5\%) cornea-heg vagy -homály, 100 esetben $(8,6 \%)$ keratoconus, 47 esetben (4,1\%) Fuchs-dystrophia, 32 esetben $(2,8 \%)$ egyéb szaruhártya-dystrophia (nem Fuchs-dystrophia), 38 esetben (3,3\%) egyéb diagnózis volt, 256 esetben $(22,1 \%)$ a szövettani diagnózis nem állt rendelkezésre (1. ábra).

A primer keratoplasztikák során felhasznált szaruhártyák 740 esetben $(63,8 \%)$ cadaverből, 215 esetben (18,6\%) multiorgan donorból származtak. 186 esetben $(17,8 \%)$ a korong származásáról nem állt rendelkezésre adat retrospektív vizsgálatunkban. A vizsgált 10 betegcsoportban a cadaverből és multiorgan donorból származó szaruhártyák megoszlását az 1 . táblázat mutatja be.

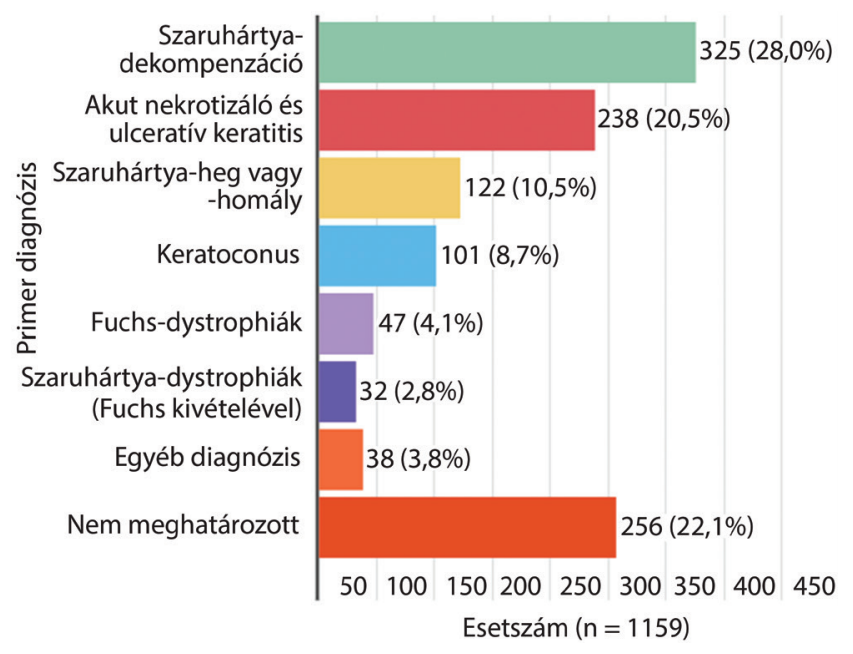

1. ábra

A primer keratoplasztikák indikációi (Brady beosztását követve) 2008 és 2017 között a Semmelweis Egyetem Szemészeti Klinikáján 
1. táblázat $\mid$ A primer keratoplasztikák során felhasznált donor szaruhártyák típusa (cadaver, multiorgan donor, hiányos dokumentáció) betegcsoportok (primer keratoplasztikához vezető diagnózis, Brady beosztását követve) szerint. A leggyakoribb diagnózist minden oszlopban dőlt számmal jelöltük

\begin{tabular}{|c|c|c|c|c|}
\hline Diagnózis & Cadaver & Multiorgan donor & Hiányos dokumentáció & Összesen \\
\hline Szaruhártya-dekompenzáció & $235(20,3 \%)$ & $63(5,4 \%)$ & $27(2,3 \%)$ & $325(28,0 \%)$ \\
\hline Akut nekrotizáló és ulceratív keratitis & $170(14,7 \%)$ & $32(2,8 \%)$ & $36(3,1 \%)$ & $238(20,5 \%)$ \\
\hline Szaruhártya-heg vagy -homály & $91(7,9 \%)$ & $18(1,6 \%)$ & $13(1,1 \%)$ & $122(10,5 \%)$ \\
\hline Keratoconus & $65(5,6 \%)$ & $21(1,8 \%)$ & $15(1,3 \%)$ & $101(8,7 \%)$ \\
\hline Fuchs-dystrophia & $23(2,0 \%)$ & $20(1,7 \%)$ & $4(0,35 \%)$ & $47(4,1 \%$ \\
\hline Szaruhártya-dystrophiák (Fuchs kivételével) & $22(1,9 \%)$ & $7(0,6 \%)$ & $3(0,26 \%)$ & $32(2,7 \%)$ \\
\hline Egyéb diagnózis & $23(2,0 \%)$ & $3(0,26 \%)$ & $12(1,0 \%)$ & $38(3,2 \%)$ \\
\hline Nem meghatározott & $111(9,6 \%)$ & $48(4,1 \%)$ & $97(8,4 \%)$ & $256(22,1 \%)$ \\
\hline Összesen & $740(63,9 \%)$ & $212(18,3 \%)$ & $207(17,9 \%)$ & $1159(100,0 \%)$ \\
\hline
\end{tabular}

\section{Elsö rekeratoplasztikák}

Első rekeratoplasztika a primer keratoplasztikák közül 217 esetben $(18,7 \%)$ történt a vizsgált időszakban, 87 esetben férfiaknál (40,1\%), 130 esetben (59,9\%) nőknél. A betegek életkora az első rekeratoplasztika idején 68,3 $\pm 14,2$ év volt, a primer keratoplasztika után átlagosan $1,5 \pm 1,4$ évvel történt ismételt mútét. Az első ismételt mútétre 52 esetben $(24,0 \%)$ egy éven belül; 79 esetben
(36,4 \%) az első mútét után több mint egy, de kevesebb mint 2 évvel; 77 esetben $(35,5 \%)$ több mint 2 , de kevesebb mint 5 évvel; 9 esetben $(4,1 \%)$ több mint 5 évvel került sor.

Első rekeratoplasztika során 146 esetben $(67,2 \%)$ korábban cadaverből származó donor esetén, 31 esetben $(14,2 \%)$ korábbi multiorgan donor felhasználását követôen került sor ismételt mútétre. 40 esetben $(18,4 \%)$ nem állt rendelkezésre információ a korábbi szaruhártya

2. táblázat $\mid$ Az első rekeratoplasztikák során explantált szaruhártyák forrása (cadaver, multiorgan donor, hiányos dokumentáció) betegcsoportok (primer keratoplasztikához vezető diagnózis, Brady beosztását követve) szerint. A leggyakoribb diagnózist minden oszlopban dőlt számmal jelöltük

\begin{tabular}{lcccc}
\hline Diagnózis & Cadaver & Multiorgan donor & Hiányos dokumentáció & Összesen \\
\hline Szaruhártya-dekompenzáció & $61(28,1 \%)$ & $11(5,1 \%)$ & $12(5,5 \%)$ & $84(38,7 \%)$ \\
\hline Ulceratív keratitis & $34(15,7 \%)$ & $7(3,2 \%)$ & $5(2,3 \%)$ & $46(21,2 \%)$ \\
\hline Szaruhártya-heg vagy -homály & $9(4,1 \%)$ & $2(0,9 \%)$ & $0(0,0 \%)$ & $11(5,1 \%)$ \\
\hline Keratoconus & $4(1,8 \%)$ & $0(0,0 \%)$ & $1(0,5 \%)$ & $6(2,8 \%)$ \\
\hline Fuchs-dystrophia & $3(1,4 \%)$ & $0(0,0 \%)$ & $1(0,5 \%)$ & $4(1,8 \%)$ \\
\hline Dystrophiák (Fuchs kivételével) & $2(0,9 \%)$ & $0(0,0 \%)$ & $1(0,5 \%)$ & $3(1,4 \%)$ \\
\hline Egyéb diagnózis & $4(1,8 \%)$ & $0(0,0 \%)$ & $0(0,0 \%)$ & $4(1,8 \%)$ \\
\hline Nem meghatározott & $29(13,4 \%)$ & $11(5,1 \%)$ & $20(9,2 \%)$ & $60(27,6 \%)$ \\
\hline Összesen & $146(67,3 \%)$ & $31(14,3 \%)$ & $40(18,4 \%)$ & $217(100,0 \%)$ \\
\hline
\end{tabular}

3. táblázat $\mid$ Az első rekeratoplasztikák során explantált szaruhártyák szövettani diagnózisa, a szaruhártyák forrása (cadaverből vagy multiorgan donorból származó) szerint. A leggyakoribb diagnózist minden oszlopban dólt számmal jelöltük

\begin{tabular}{lcccc}
\hline Diagnózis & Cadaver & Multiorgan donor & Hiányos dokumentáció & Összesen \\
\hline Endothelsejt-degeneráció & $89(41,0 \%)$ & $21(9,7 \%)$ & $21(9,7 \%)$ & $131(60,4 \%)$ \\
\hline Ulceratív keratitis & $31(14,3 \%)$ & $4(1,8 \%)$ & $6(2,8 \%)$ & $41(18,9 \%)$ \\
\hline Szaruhártya-heg vagy -homály & $4(1,8 \%)$ & $2(0,9 \%)$ & $1(0,5 \%)$ & $7(3,2 \%)$ \\
\hline Transzplantátum-nekrózis, -neovaszkularizáció & $2(0,9 \%)$ & $0(0,0 \%)$ & $1(0,5 \%)$ & $3(1,4 \%)$ \\
\hline Kilökődési reakció & $0(0,0 \%)$ & $1(0,5 \%)$ & $1(0,5 \%)$ & $2(0,9 \%)$ \\
\hline Szaruhártya-dystrophia & $2(0,9 \%)$ & $0(0,0 \%)$ & $0(0,0 \%)$ & $2(0,9 \%)$ \\
\hline Egyéb diagnózis & $3(1,4 \%)$ & $0(0,0 \%)$ & $0(0,0 \%)$ & $3(1,4 \%)$ \\
\hline Nem meghatározott & $15(6,9 \%)$ & $3(1,4 \%)$ & $10(4,6 \%)$ & $28(12,9 \%)$ \\
\hline Összesen & $146(67,3 \%)$ & $31(14,3 \%)$ & $40(18,4 \%)$ & $217(100,0 \%)$ \\
\hline
\end{tabular}


forrásáról. Az első rekeratoplasztika során 143 esetben $(65,9 \%)$ cadaverból, 50 esetben $(23,0 \%)$ multiorgan donorból származó donor került felhasználásra, 25 esetben (11,5\%) nem állt rendelkezésre adat a donor származásáról.

Az eltávolított szaruhártya forrását az egyes betegcsoportokban a 2. táblázat tartalmazza. Az első rekeratoplasztikák során eltávolított szaruhártyakorongok szövettani diagnózisa 130 esetben $(60,4 \%)$ endothelsejtdegeneráció, 41 esetben (18,9\%) ulceratív keratitis, 7 esetben $(3,2 \%)$ szaruhártya-heg vagy -homály, 3 esetben $(1,4 \%)$ transzplantátum-nekrózis vagy -neovaszkularizáció, 2 -2 esetben $(0,9 \%, 0,9 \%)$ cornea-dystrophia, illetve kilökődési reakció, 3 esetben (1,4\%) egyéb indikáció volt, és 28 esetben (12,9\%) szövettani elemzés nem állt rendelkezésre (3. táblázat).

\section{Második, harmadik, negyedik rekeratoplasztikák}

$\mathrm{Az}$ általunk vizsgált betegpopuláción belül 56 esetben, azaz az első rekeratoplasztikán átesett betegek 25,8\%-nál volt szükség második rekeratoplasztikára [11 férfi $(19,6 \%), 45$ nő $(80,4 \%)]$. Az életkor a második rekeratoplasztika idején $68,5 \pm 11,9$ év volt, az első rekeratoplasztika után átlagosan $1,7 \pm 1,5$ évvel történt ismételt mütét. Az első rekeratoplasztikánál felhasznált 37 $(66,1 \%)$ cadaver és $15(26,8 \%)$ multiorgan donorból származó szaruhártya esetén történt második rekeratoplasztika, 4 esetben $(7,1 \%)$ a donor típusáról nem állt rendelkezésre adat. Második rekeratoplasztika során 45 esetben $(80,4 \%)$ cadaverból, 11 esetben $(19,6 \%)$ multiorgan donorból származó szaruhártyát használtunk fel.

Harmadik rekeratoplasztika összesen 16 esetben [7 férfi $(43,8 \%), 9$ nő $(56,2 \%)]$, azaz a második rekeratoplasztikán átesett betegek 28,1\%-ánál történt. Az életkor a harmadik rekeratoplasztika idején $66,4 \pm 12,5$ év volt, a második rekeratoplasztika után átlagosan 1,4 \pm 1,3 év telt el ekkor. A második rekeratoplasztikánál felhasznált $14(87,5 \%)$ cadaver és $2(12,5 \%)$ multiorgan donorból származó szaruhártya esetén történt harmadik rekeratoplasztika, melynek során 9 esetben $(56,2 \%)$ cadaverből, 7 esetben $(43,8 \%)$ multiorgan donorból származó szaruhártyát használtunk fel.

Negyedik rekeratoplasztika összesen kettő történt, a harmadik mútéten átesett betegek 12,5\%-ánál. Az egyik beteg egy 68 éves nő volt, akinek az első szaruhártyaátültetése akut nekrotizáló és ulceratív keratitis miatt történt. A harmadik rekeratoplasztika után 3 évvel - szintén ulceratív keratitis miatt - multiorgan donor helyett cadaverből származó szaruhártyát kapott. A másik, egy 53 éves férfibeteg esetén 1 évvel az elóző mütétet követően endothelsejt-degeneráció miatt volt szükség újabb szaruhártya-átültetésre, az első mútétet követő szövettani diagnózis nem állt rendelkezésre. A mútét során multiorgan donorból származó szaruhártyáját cadaverből származó korongra cseréltük. 2 évvel később szükségessé vált az 5. rekeratoplasztika elvégzése, szintén cadaverból származó szaruhártya felhasználásával. Szövettani diag-

4. táblázat A második, harmadik, negyedik, ötödik rekeratoplasztikák során explantált szaruhártyák forrása (cadaver, multiorgan donor, hiányos dokumentáció) betegcsoportok (primer keratoplasztikához vezető diagnózis, Brady beosztását követve) szerint. A leggyakoribb diagnózist/diagnózisokat minden oszlopban dőlt számmal jelöltük

\begin{tabular}{|c|c|c|c|c|}
\hline Diagnózis & Cadaver & Multiorgan donor & Hiányos dokumentáció & Összesen \\
\hline Szaruhártya-dekompenzáció & $19(25,3 \%)$ & $6(8,0 \%)$ & $1(1,3 \%)$ & $26(34,7 \%)$ \\
\hline Akut nekrotizáló és ulceratív keratitis & $20(26,7 \%)$ & $6(8,0 \%)$ & $1(1,3 \%)$ & $27(36,0 \%)$ \\
\hline Szaruhártya-heg vagy -homály & $1(1,3 \%)$ & $0(0,0 \%)$ & $0(0,0 \%)$ & $1(1,3 \%)$ \\
\hline Szaruhártya-dystrophiák (Fuchs kivételével) & $1(1,3 \%)$ & $0(0,0 \%)$ & $0(0,0 \%)$ & $1(1,3 \%)$ \\
\hline Nem meghatározott & $11(14,7 \%)$ & $7(9,3 \%)$ & $2(2,7 \%)$ & $20(26,7 \%)$ \\
\hline Összesen & $52(69,3 \%)$ & $19(25,3 \%)$ & $4(5,3 \%)$ & $75(100,0 \%)$ \\
\hline
\end{tabular}

\begin{tabular}{lcccc}
\hline Diagnózis & Cadaver & Multiorgan donor & Hiányos dokumentáció & Összesen \\
\hline Endothelsejt-degeneráció & $25(33,3 \%)$ & $10(13,3 \%)$ & $2(2,7 \%)$ & $37(49,3 \%)$ \\
\hline Ulceratív keratitis & $10(13,3 \%)$ & $4(5,3 \%)$ & $1(1,3 \%)$ & $15(20,0 \%)$ \\
\hline Szaruhártya-heg vagy -homály & $4(5,3 \%)$ & $1(1,3 \%)$ & $0(0,0 \%)$ & $5(6,7 \%)$ \\
\hline Transzplantátum-nekrózis, -neovaszkularizáció & $2(2,7 \%)$ & $1(1,3 \%)$ & $1(1,3 \%)$ & $4(5,3 \%)$ \\
\hline Egyéb diagnózis & $2(2,7 \%)$ & $0(0,0 \%)$ & $0(0,0 \%)$ & $2(2,7 \%)$ \\
\hline Nem meghatározott & $10(13,3 \%)$ & $3(4,0 \%)$ & $0(0,0 \%)$ & $13(17,3 \%)$ \\
\hline Öszesen & $53(70,6 \%)$ & $19(25,3 \%)$ & $4(5,3 \%)$ & $76(100,0 \%)$ \\
\hline
\end{tabular}




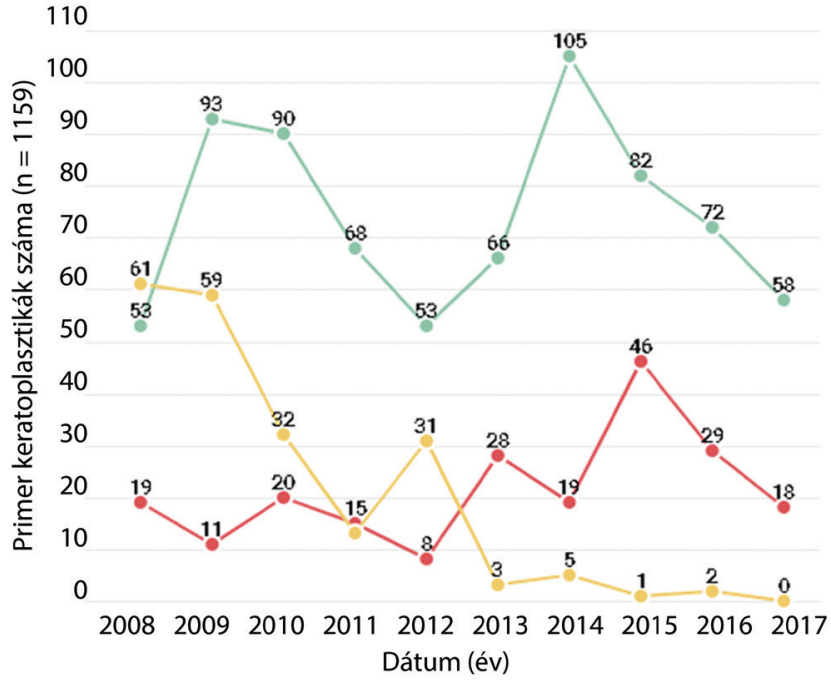

Cadaver Multiorgan donor Hiányos dokumentáció

2. ábra

A primer keratoplasztikák során felhasznált donor szaruhártyák száma és típusa (cadaver, multiorgan donor, hiányos dokumen táció) évenkénti bontásban 2008 és 2017 között a Semmelweis Egyetem Szemészeti Klinikáján

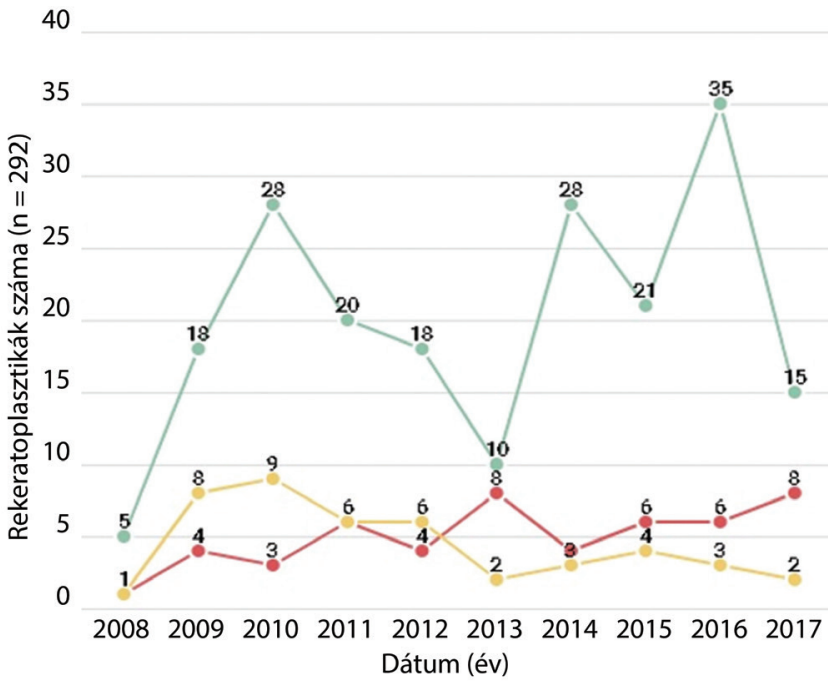

Cadaver Multiorgan donor Hiányos dokumentáció

3. ábra A rekeratoplasztikák során (első, második, harmadik, negyedik,
ötödik rekeratoplasztikák összesítve) explantált donor szaruhár-
tyák száma és típusa (cadaver, multiorgan donor, hiányos doku-
mentáció) évenkénti bontásban 2008 és 2017 között a Semmel-
weis Egyetem Szemészeti Klinikáján

nózisra vonatkozó adatot (a 4. eltávolított korongra vonatkozólag) ebben az esetben nem találtunk.

A második, harmadik, negyedik és ötödik rekeratoplasztikák során eltávolított szaruhártyák forrását betegcsoportok szerint a 4. táblázat, szövettani diagnózisok szerint az 5. táblázat tartalmazza. Az 5. táblázatban az elemszám eggyel magasabb, mivel egy esetben a szövettani vizsgálat endothelsejt-degenerációt és ulceratív keratitist egyaránt igazolt.

\section{Keratoprotézis felhasználása keratoplasztikával egyidejüleg}

Primer keratoplasztikánál 21 esetben $(1,8 \%)$, első rekeratoplasztikánál 5 esetben $(2,3 \%)$, második rekeratoplasztikánál 7 esetben $(12,5 \%)$, harmadik rekeratoplasztikánál 2 esetben $(12,5 \%)$ keratoprotézis beültetése is történt. Negyedik rekeratoplasztikánál erre nem volt példa, míg az egyetlen, 5. rekeratoplasztikán átesett beteg is kapott keratoprotézist (100\%).

\section{Megbeszélés}

Hazánkban 1993 óta múködik szaruhártya-bank [4], a graftok cadaverból és multiorgan donorokból származnak. Tudomásunk szerint jelen munkánk az első vizsgálat, amely Magyarországon, egy központon belül a cadaverből és multiorgan donorból származó szaruhártyák felhasználását és azok túlélését vizsgálja. Klinikánkon 2008-2017 között 1088 beteg 1159 szemén, 1451 alkalommal történt szaruhártya-átültetés, melyekből 938 cadaver és 262 multiorgan donor került felhasználásra (25l esetben nem állt rendelkezésre adat).

A Semmelweis Egyetem Szemészeti Klinikáján 2008 és 2017 között primer keratoplasztikák esetén 64\%-ban cadaverből, 18,6\%-ban multiorgan donorból származó szaruhártya került felhasználásra, 16\%-ban nem állt rendelkezésre adat. Tudomásunk szerint más európai intézetben cadaver és multiorgan donor egyidejú felhasználása nem történik, legalábbis erról az irodalomban (valamint a European Eye Bank Association weboldalán) nem érhető el információ. Patel és mtsainak Új-Zélandon végzett tanulmánya mindössze 7,1\%-ban írta le multiorgan donorból származó donorok felhasználását [13]. Williams és mtsai Ausztráliában mindössze 5\%-nak írták le a multiorgan donorok arányát a transzplantációnál felhasznált szövetek között [14]. Hazánkban és egyetemünkön a multiorgan donorok aránya mind az ausztrál, mind az új-zélandi centruménál nagyobb volt. A Szervkoordinációs Iroda és a 2004 óta klinikánkon múködő Semmelweis Cornea Bank jól szervezett munkájának és együttmúködésének köszönhetô, hogy egyetemünkön primer keratoplasztikák esetén 18,6\%-ban (10 év alatt legalább 325 esetben) kerülhettek multiorgan donorok felhasználásra. Klinikánkon a multiorgan donorok harvesztálására állandó ügyeleti szolgálatot tartunk fenn, így van lehetőségünk a Szervkoordinációs Irodától kapott értesítést követően a harvesztáláshoz kivonulni.

Vizsgált betegpopulációnkban a recipiensek életkora a mútét idején, primer keratoplasztika esetén $62,8 \pm 18,5$ év volt. A keratoplasztika fó indikációja földrajzi régiónként eltérő [15], és az egyes diagnózisok gyakoriságai különböző életkori megoszlást mutatnak. Németországban, az Egyesült Királyságban és Olaszországban az elsősorban fiatal férfiakat érintő keratoconus a leggyakoribb mútéti indikáció, ezért a betegek átlagos életkora a beavatkozás idején alacsonyabb (57,6 \pm 18,7 év) [16]. 
Ezzel szemben Magyarországon, 1999 és 2003 között a leggyakoribb a pseudophakiás és aphakiás bullosus keratopathia volt [17], mely az idősebb korosztályban gyakoribb. A vizsgált időszakban, hazánkban a három leggyakoribb primer diagnózis a szaruhártya-dekompenzáció (325 eset, 28,1\%), az akut nekrotizáló és ulceratív keratitis (238 eset, 20,5\%) és a cornea-heg vagy -homály (122 esetben, 10,5\%) volt. A keratoconus 1946 és 2009 között csupán a harmadik [10], eredményeink alapján a negyedik leggyakoribb primer diagnózis volt. Mindezt az magyarázza, hogy hazánkban más országokhoz képest magasabb az átlagéletkor.

A keratitisek közül az Acanthamoeba-keratitis prevalenciája a kontaktlencse-viselök számának növekedésével világszerte emelkedik. A betegség gyors progressziója miatt gyakran a keratoplasztika az egyetlen terápiás lehetőség, ugyanakkor az Acanthamoeba-keratitis miatt végzett szaruhártya-átültetések az általunk vizsgált időszakban is ritkák maradtak $[18,19]$.

Mind primer keratoplasztikák, mind rekeratoplasztikák esetén a leggyakoribb szövettani diagnózis a szaruhártya-dekompenzáció volt. Megfigyelhető, hogy a primer keratoplasztikáknál 28\%-ban, első rekeratoplasztikáknál már 38,7\%-ban volt szaruhártya-dekompenzáció a szövettani diagnózis. Vizsgálatunk során első rekeratoplasztika a primer keratoplasztikák közül 217 esetben $(18,7 \%)$ történt. A rekeratoplasztika szükségességének aránya az Új-Zélandon végzett kutatási eredményekhez hasonló (17\%) [20], míg Kanadában nagyobb arányban, 26,9\%-ban, az Egyesült Királyságban 40,9\%-ban volt szükség ismételt mütéti beavatkozásra [21, 22]. A rekeratoplasztikák rosszabb prognózisúak a primer mútétekhez képest, ezek mind egy-, mind többváltozós elemzésekben jelentős kockázati tényezőnek bizonyultak [23].

A rekeratoplasztikák során explantált szaruhártyákból vett szövettani vizsgálatok leggyakrabban endothelsejtdegenerációt (168 eset, 57,5\%), majd ulceratív keratitist (56 eset, 19,2\%) igazoltak. Eredményeink összhangban vannak egy korábban, Németországban és Angliában végzett tanulmány adataival, miszerint a leggyakoribb szövettani diagnózis ugyancsak az endothelialis diszfunkció, majd az ulceratív keratitis volt [16, 22].

A szaruhártya endotheliumának túlélését számos tényező befolyásolhatja. Ezek közé tartozik a donor szaruhártya endothelsejt-száma, a postmortem idő (a keringés leállása és a harvesztálás között eltelt idő), a donor harvesztálást követő felhasználási ideje és a donor életkora is [24-26].

A legfrissebb bizonyítékok arra utalnak, hogy a donor életkora helyett a beültetett szaruhártya hosszú távú túlélésének prediktora az endothelsejtek száma [12, 25]. Nincs egységes álláspont arra vonatkozóan, hogy pontosan milyen endothelsejt-denzitás (ECD) alatt alakul ki szaruhártya-dekompenzáció [27, 28]. Az alacsony ECD-n $\left(\leq 1700 \mathrm{~mm}^{2}\right)$ kívül a magas szaruhártya-vastagság $(\geq 600 \mu \mathrm{m})$ a mütétet követő 6 hónapon belül, majd 1 és 5 évvel később mérve korrelál a graftelégtelenség megnövekedett valószínúségével. Az utánkövetés során az ECD és a szaruhártya-vastagság ismeretében következtetéseket vonhatunk le a kilökődés kockázatával kapcsolatban [29].

A postmortem idő a szaruhártya intracelluláris metabolizmusát befolyásolja. A Semmelweis Cornea Bank 24 órán belüli postmortem időt fogad el a potenciális donorok értékelése során [30]. Böhringer és mtsai szignifikáns ECD-csökkenést mértek a postmortem idő növekedésével párhuzamosan, a kedvezőtlen hatást a szövettenyészetben létrejövő metabolikus és génexpressziós változásoknak tulajdonították [25]. A Langenbucher által készített tanulmány szerint azonban a krónikus endothelsejtszám-csökkenés nem korrelál a postmortem idővel [28].

Patel és mtsai szerint a donor harvesztálást követő hosszabb felhasználási ideje Mc-Carey-Kaufman, K-Sol medium alkalmazása mellett $\left(+4^{\circ} \mathrm{C}\right)$ nem jelent kockázatot a graftelégtelenség szempontjából [31]. Wagoner és $m$ tsai [32] a Singapore Corneal Tranplant Study eredményeivel összhangban [33] Optisol használatakor nem találtak összefüggést a tárolási idő ( $\mathrm{t} \geq 7$ nap) és a graftelégtelenség kialakulása között [32].

Európában, a legtöbb országban a donor szaruhártyákat $+37^{\circ} \mathrm{C}$-on, szervtenyészetben tárolják. A donor harvesztálást követő felhasználási ideje így 4 hétre növelhető, és a 4 hetes tárolási idő sem korrelál a graft- és varratelégtelenséggel, a kilökődés valószínüségével és az ECD-vel [34]. Továbbá az endothelialis dekompenzáció kialakulása nem függ a halál és a preparálás között eltelt időtől, a tárolási időtől [35-37] és a tárolás módjától sem [28].

A donor életkorának szerepe vitatott. A Cornea Donor Study a donor életkorának szerepét csak szélsőséges esetekben írja le jelentősnek [38]. Barraquer és mtsai szerint a donor életkora - 10 és 90 év között - a perforáló keratoplasztika utáni 5 évben nem befolyásolja szignifikánsan a graft túlélését [23].

Sajnos jelen retrospektív tanulmányunk esetén a donor szaruhártya endothelsejt-száma, a postmortem idő és a donor harvesztálást követő felhasználási ideje nem állt rendelkezésre, ezeknek az adatoknak jelentős része a banki tevékenység során nem került meghatározásra. Célunk a jövőben mindezen adatok prospektív gyưjtése, ezzel is javítva a szaruhártya-banki tevékenységet és csökkentve a rekeratoplasztikák szükségességét.

Adatainknál megfigyelhetjük, hogy míg primer keratoplasztikáknál 64\%-ban cadaverből származó szaruhártya került felhasználásra, addig az első rekeratoplasztikánál mintegy 67,2\%-ban korábban cadaverből származó graft esetén volt szükséges ismételt mútét. A második, harmadik és negyedik keratoplasztika esetén az előző keratoplasztikánál cadaverből származó szaruhártyák aránya már 73,2\% volt. Noha megfigyelhető volt az a tendencia, hogy inkább a cadaverből felhasználásra kerülő szaruhártyák esetén volt szükséges ismételt mútét, egyértelmű különbséget cadaverből és multiorgan donorból 
származó szaruhártyakorongok között nem lehetett igazolni. Pontos elemzéshez a donor szaruhártya endothelsejt-számának, a postmortem időnek, a donor harvesztálást követő felhasználási idejének és a donor életkorának ismerete szükséges. Az a tendencia, hogy a multiorgan donorból származó szaruhártyák túlélése legalább olyan kedvező, mint a cadaverből származóké, feltehetőleg annak köszönhető, hogy a postmortem idő rövid és a donorok életkora jellemzően alacsony.

Természetesen a donor szaruhártyák recipiensben történő túlélését a recipiens klinikai diagnózisa is meghatározza. Dorrepaal és mtsai szerint szaruhártya-dekompenzáció esetén 18,9\%-ban kerül sor rekeratoplasztikára [21], és ebben az esetben a legnagyobb a rekeratoplasztikák százalékos aránya minden más diagnóziscsoporthoz képest. Patel és mtsai szerint a graftelégtelenség leggyakoribb oka a kései endothelsejt-dekompenzáció (31\%) [31]. Böhringer és mtsai szerint irreverzibilis graftelégtelenség bullosus keratopathia esetén alakul ki a legnagyobb arányban $(31 \%)$ a rekeratoplasztikát követő 5 éven belül $[39,40]$.

Tanulmányunk leírja a donor szaruhártyák típusát és a rekeratoplasztikáig eltelt időt, azonban számos tényezőt, így például az átültetett szaruhártyák méretét, a műtéti technikát, a felhasznált varratok típusát, a betegek kooperációjának vagy akár a sebésznek a szerepét, az alkalmazott lokális, illetve szisztémás kezelés hatását nem vizsgálja. Cadaverből, illetve multiorgan donorokból származó szaruhártyák felhasználása ezektől a faktoroktól függetlenül történt a vizsgált időszakban, ezért szerepüket nem tartjuk jelen nagy esetszámú tanulmányunk tekintetében döntőnek. Ugyanakkor egy későbbi, több adatot részletező és vizsgáló tanulmány segíthet tovább javítani a betegek korszerű ellátását és a szaruhártyák túlélését.

\section{Következtetés}

Összefoglalva elmondhatjuk, hogy klinikánkon elsősorban cadaverból származó donorok biztosítják a primer és ismételt szaruhártya-átültetésekhez szükséges szövetet. Cadaverből vagy multiorgan donorból származó szaruhártyák felhasználását követően nem kerül gyakrabban sor rekeratoplasztikára. A szaruhártya-banki tevékenység fejlesztésével, a postmortem idő, a szövetkultúrában eltöltött idő és az endothelsejt-szám pontos meghatározásával tovább javítható a szaruhártya-banki tevékenység hazánkban és klinikánkon.

Anyagi támogatás: A közlemény megírása, illetve a kutatómunka anyagi támogatásban nem részesült.

Szerzői munkamegosztás: K. K., Sz. N., P. M. T., K. D.: Adatgyứjtés. K. K., Sz. N., K. H., F. Á., R. G., M. A.: Irodalomgyújtés. Sz. N., L. A.: A statisztika elkészítése.
K. K., Sz. N., N. Z. Zs.: A kézirat megszövegezése és javítása. A cikk végleges változatát valamennyi szerző elolvasta és jóváhagyta.

Érdekeltségek: A szerzőknek nincsenek érdekeltségeik.

\section{Irodalom}

[1] Pascolini D, Mariotti SP. Global estimates of visual impairment: 2010. Br J Ophthalmol. 2012; 96: 614-618.

[2] Németh O, Tapasztó B, Tar S, et al. Corneal deposits in monoclonal gammopathy of undetermined significance. Review of the literature and case report. [Szaruhártya-lerakódások bizonytalan jelentőségú monoklonális gammopathiában. Irodalmi áttekintés és esetbemutatás.] Orv Hetil. 2018; 159: 1575-1583. [Hungarian]

[3] Lambert NG, Chamberlain WD. The structure and evolution of eye banking: a review on eye banks' historical, present, and future contribution to corneal transplantation. J Bioreposit Scie Applied Med. 2017; 5: 23-40.

[4] Cornea Bank Budapest. [Cornea Bank Budapest.] Available: corneabank.hu [accessed: August 2, 2020]. [Hungarian]

[5] Armitage WJ, Tullo AB, Larkin DF. The first successful fullthickness corneal transplant: a commentary on Eduard Zirm's landmark paper of 1906. Br J Ophthalmol. 2006; 90: 12221223.

[6] History of Corneal Transplantation, Eye Banking and the EBAA. Available: restoresight.org/wp-content/uploads/2012/02/ History-Corneal-Transplants-Eye-Banking-and-the-EBAA.pdf [accessed: August 2, 2020].

[7] Moffatt SL, Cartwright VA, Stumpf TH. Centennial review of corneal transplantation. Clin Exp Ophthalmol. 2005; 33: 642657.

[8] Anderson J, Ehlers N. Corneal transplantation using long-term cultured donor material. Acta Ophthalmol. 1986; 64: 93-96.

[9] Fejér G. On the current concept of keratoplasty. [A keratoplasztika jelenlegi koncepciójáról.] Szemészet 1910; 47: 52. [Hungarian]

[10] Módis L Jr, Szalai E, Facskó A, et al. Corneal transplantation in Hungary (1946-2009). Clin Exp Ophthalmol. 2011; 39: 520525.

[11] Jones GL, Dekaris I, Hjortdal J, et al. European Eye Bank Association: Past, present, and future. Int J Eye Bank. 2012; 1: $1-6$.

[12] Williams KA, Esterman AJ, Bartlett C, et al. How effective is penetrating corneal transplantation? Factors influencing longterm outcome in multivariate analysis. Transplantation 2006; 81: 896-901.

[13] Patel HY, Brookes NH, Moffatt L, et al. The New Zealand National Eye Bank Study 1991-2003. Cornea 2005; 24: 576-582.

[14] Williams KA, Lowe M, Bartlett C, et al. Risk factors for human corneal graft failure within the Australian Corneal Graft Registry. Transplantation 2008; 86: 1720-1724.

[15] Matthaei M, Sandhaeger H, Hermel M, et al. Changing indications in penetrating keratoplasty: a systematic review of 34 years of global reporting. Transplantation 2017; 101: 1387-1399.

[16] Pluzsik MT, Seitz, B, Flockerzi FA, et al. Changing trends in penetrating keratoplasty indications between 2011 and 2018 Histopathology of 2123 corneal buttons in a single center in Germany. Curr Eye Res. 2020; 145: 1199-1204.

[17] Szentmáry N, Bausz M, Tóth J, et al. Eleven years of corneal transplantation (1992-2003) at the Semmelweis University lst Department of Ophthalmology. [A cornea transzplantáció 11 éve (1992-2003).] Szemészet 2004; 141: 387-391. [Hungarian] 
[18] Orosz E, Kriskó D, Shi L, et al. Clinical course of Acanthamoeba keratitis by genotypes T4 and T8 in Hungary. Acta Microbiol Immunol Hung. 2019; 66: 289-300.

[19] Orosz E, Szentmáry N, Kiss HJ, et al. First report of Acanthamoeba genotype T8 human keratitis. Acta Microbiol Immunol Hung. 2018; 65: 73-79.

[20] Cunningham WJ, Brookes NH, Twohill HC, et al. Trends in the distribution of donor corneal tissue and indications for corneal transplantation: the New Zealand National Eye Bank Study 2000-2009. Clin Exp Ophthalmol. 2012; 40: 141-147.

[21] Dorrepaal SJ, Cao KY, Slomovic AR. Indications for penetrating keratoplasty in a tertiary referral centre in Canada, 1996-2004. Can J Ophthalmol. 2007; 42: 244-250.

[22] Al-Yousuf N, Mavrikakis I, Mavrikakis E, et al. Penetrating keratoplasty: indications over a 10 year period. Br J Ophthalmol. 2004; 88: 998-1001.

[23] Barraquer RI, Pareja-Aricò L, Gómez-Benlloch A, et al. Risk factors for graft failure after penetrating keratoplasty. Medicine (Baltimore) 2019; 98: el5274

[24] Sugar J, Montoya M, Dontchev M, et al. Donor risk factors for graft failure in the Cornea Donor Study. Cornea 2009; 28: 981985.

[25] Böhringer D, Reinhard T, Spelsberg H, et al. Influencing factors on chronic endothelial cell loss characterised in a homogeneous group of patients. Br J Ophthalmol. 2002; 86: 35-38.

[26] Williams KA, Muehlberg SM, Lewis RF, et al. Influence of advanced recipient and donor age on the outcome of corneal transplantation. Br J Ophthalmol. 1997; 81: 835-839.

[27] Módis L, Szalai E, Flaskó Z, et al. Femtosecond laser-assisted keratoplasty. [Femtoszekundumlézeres keratoplasztika.] Orv. Hetil. 2018; 159: 671-676. [Hungarian]

[28] Langenbucher A, Nguyen NX, Seitz B. Predictive donor factors for chronic endothelial cell loss after nonmechanical penetrating keratoplasty in a regression model. Graefes Arch Clin Exp Ophthalmol. 2003; 241: 975-981.

[29] Bachmann B, Taylor RS, Cursiefen C. Corneal neovascularization as a risk factor for graft failure and rejection after keratoplasty: An evidence-based meta-analysis. Ophthalmology 2010; 117: 1300-1305.e7.
[30] Kryczka T, Szaflik JP, Szaflik J, et al. Influence of donor age, post-mortem time and cold storage on metabolic profile of human cornea. Acta Ophthalmol. 2013; 91: 83-87.

[31] Patel SV, Diehl NN, Hodge DO, et al. Donor risk factors for graft failure in a 20 -year study of penetrating keratoplasty. Arch Ophthalmol. 2010; 128: 418-425.

[32] Wagoner MD, Gonnah el-S. Corneal graft survival after prolonged storage in Optisol-GS. Cornea 2005; 24: 976-979.

[33] Tan DT, Janardhanan P, Zhou H, et al. Penetrating keratoplasty in Asian eyes: The Singapore Corneal Transplant Study. Ophthalmology 2008; 115: 975-982.el.

[34] Madzak A, Hjortdal J. Outcome of human donor corneas stored for more than 4 weeks. Cornea 2018; 37: 1232-1236.

[35] Lass JH, Beck RW, Benetz BA, et al. Baseline factors related to endothelial cell loss following penetrating keratoplasty. Arch Ophthalmol. 2011; 129: 1149-1154.

[36] Yu AL, Kaiser M, Schaumberger M, et al. Donor-related risk factors and preoperative recipient-related risk factors for graft failure. Cornea 2014; 33: 1149-1156.

[37] Armitage WJ, Jones MN, Zambrano I, et al. The suitability of corneas stored by organ culture for penetrating keratoplasty and influence of donor and recipient factors on 5-year graft survival. Invest Ophthal Vis Sci. 2014; 55: 784-791.

[38] Sugar A, Gal RL, Kollman C, et al. Factors associated with corneal graft survival in the Cornea Donor Study. JAMA Ophthalmol. 2015; 133: 246-254.

[39] Böhringer D, Reinhard T. Prognosis in repeat keratoplasty: per indication analysis in a large monocentric cohort. [Die Prognose der Rekeratoplastik: Indikationsbezogene Analysen in einer grossen monozentrischen Kohorte.] Klin Mbl Augenheilkd. 2008; 225: 50-56. [German]

[40] Park CY, Lee JK, Gore PK, et al. Keratoplasty in the United States: a 10-year rewiev from 2005 trough 2014. Ophthalmology 2015 ; 122: 2432-2442

(Kovács Klaudia dr., Budapest, Mária u. 39., 1085 e-mail: kovacs.klaudia@med.semmelweis-univ.hu)

\section{"Vulnerando sanamus." (Sebet ejtve gyógyítunk.)}

A cikk a Creative Commons Attribution 4.0 International License (https://creativecommons.org/licenses/by/4.0/) feltételei szerint publikált Open Access közlemény, melynek szellemében a cikk bármilyen médiumban szabadon felhasználható, megosztható és újraközölhetö, feltéve, hogy az eredeti szerző és a közlés helye, illetve a CC License linkje és az esetlegesen végrehajtott módosítások feltüntetésre kerülnek. (SID_1) 